\title{
Overview and perspectives about the robotic surgical certification process in Brazil: the new statement and a national web-survey
}

\section{Visão geral e perspectivas sobre o processo de certificação em cirurgia robótica no Brasil: o novo regimento e uma pesquisa nacional online}

Raphael L. C. Araujo, TCBC-SP1,2 (DiD; Dyego Sa Benevenuto, TCBC-RJ33; Bruno Zilberstein, ECBC-SP4,5; Rubens A. Sallum, TCBC-SP5; Samuel Aguiar-Jr6; Leandro Totti Cavazzola, TCBC-RS7,8; Miguel Nacul, TCBC-RS9; Armando G. F. Melani, TCBC-SP10,11; Flávio D. S. TOMASICH, TCBC-PR ${ }^{12}$.

\section{A B S T R A C T}

\begin{abstract}
Objective: to appraise the general profile of the Brazilian robotic surgeon and the acknowledgment of the new certification process for robotic surgery upon the Associação Médica Brasileira (AMB - Brazilian Medical Association) statement. According to the AMB statement, medical societies and proctors have to achieve leading roles in training and certification of surgeons, acting in partnership with industry. Methods: a national web-based survey was promoted by the Colégio Brasileiro de Cirurgiões (CBC - Brazilian College of Surgeons) among their members. Results: the 294 answers were split into two groups: 133 (45.3\%) who had robotic console certification, and 161 (54.8\%) who did not have it. The overall median age was 46, but the non-robotic group presented more surgeons with at least 30 years of experience than to the robotic group ( $32.3 \%$ versus $23.3 \%, p=0.033$ ). Surgeons with robotic certification more frequently work in a city with at least one million inhabitants than surgeons who were not certified ( 85.7 versus $63.4 \%, p<0.001)$. The majority of surgeons in both groups have similar positioning for all main points of the statement. However, the agreement proportions for the preceptors responsibility during the procedures were higher among non-robotic surgeons that expected the preceptor to assume co-responsibility for the procedure ( $85 \%$ versus $60.9 \%, p<0.001)$, and intervene during the procedure as much as necessary $(97.5 \%$ versus $91.7 \%, p=0.033$ ). Conclusion: the overall agreement of the answers to the AMB statement seems to be a promising pathway to increase the participation of the medical entities into the robotic certification in Brazil.
\end{abstract}

Keywords: Robotics. Certification. Minimally Invasive Surgical Procedures. Training Support.

\section{INTRODUCTION}

S ince its first use in 1985, robotic surgery in humans has been in the spotlight of the surgical community?. The acceptance of robotic surgery has improved the portfolio of minimally invasive surgery and become the counterpoint to laparoscopy. Although its attractiveness has increased, currently with more than 5,000 thousand units worldwide, its cost and access to the robotic certification has limited the robotic use. The robotic platform da Vinci® was approved by the Food and Drug Administration - USA (FDA) in 2000, and its recommendation by the National Institute for Health and Care Excellence - UK (NICE) in 2015. These are two important landmarks for robotic acceptance and worldwide diffusion.

Meanwhile, robotic surgery has become more common in Brazil, in many different specialties, and the Associação Médica Brasileira (AMB - Brazilian Medical Association) published a statement about the robotic

1 - Universidade Federal de São Paulo, Department of Digestive Surgery - São Paulo - São Paulo - Brasil 2 - Hospital Israelita Albert Einstein, Department of Oncology - São Paulo - São Paulo - Brasil 3 - Hospital Copa D'or, Service of Surgery - Rio de Janeiro - RJ - Brasil 4 - Faculdade de Medicina SL Mandic, Service of Digestive Surgery - Campinas - São Paulo - Brasil 5 - Universidade de São Paulo, Department of Digestive Surgery - São Paulo - SP - Brasil 6 - Hospital AC Camargo, Department of Colorectal Surgery - São Paulo - SP - Brasil 7 - Universidade Federal do Rio Grande do Sul, Department of Surgery - Porto Alegre - RS - Brasil 8 - Hospital das Clínicas de Porto Alegre, Service of General Surgery - Porto Alegre - RS - Brasil 9 - Hospital Moinhos de Vento, Service of Surgery - Porto Alegre - RS - Brasil 10 - Americas Serviços Medicos, Service of Colorectal Surgery - Rio de Janeiro - RJ Brasil 11 - IRCAD America Latina, IRCAD - Rio de Janeiro - RJ - Brasil 12 - Universidade Federal do Paraná, Department of Surgery - Curitiba - PR - Brasil 
certification process in Brazil, in December 2019². All surgical societies that use robotic platforms together with the AMB published a new robotic certification statement to grant future robotic surgeons and societies, in their respective areas of expertise, the ability to certify the professionals ${ }^{2}$. This study aimed to evaluate the opinion and knowledge, in regard to the new directives of the $A M B$, among Brazilian surgeons who are members of the Colégio Brasileiro de Cirurgiões (CBC - Brazilian College of Surgeons). This was a web-survey.

\section{METHODS}

A national web-based cross-sectional survey was carried out, and the questionnaires were sent by e-mail to all members of the CBC. The first step was to send an invitation to all members of the College including a link to the survey; and the second step was to resend the invitation for those members who had received the email, but had not opened it, as depicted in Figure 1.

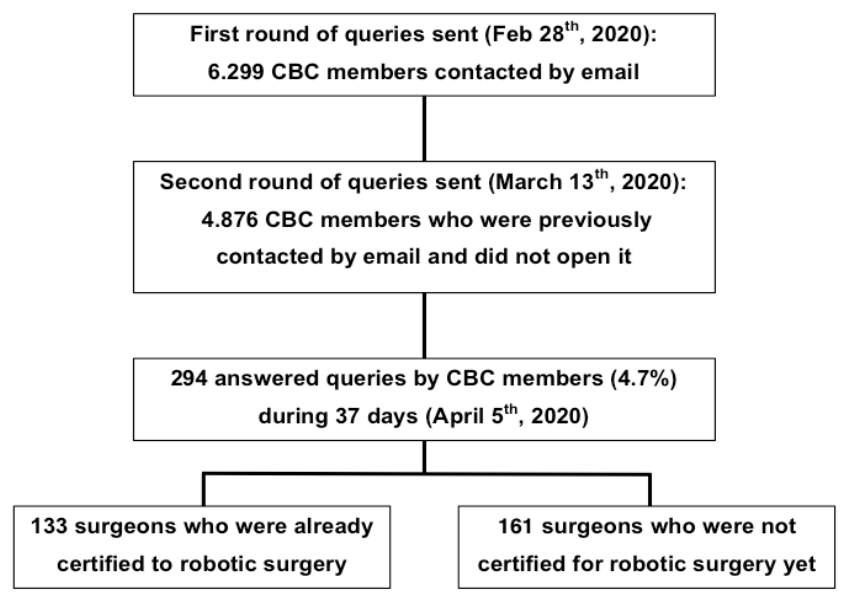

Figure 1. Data collection strategy. Colégio Brasileiro de Cirurgiões (CBC - Brazilian College of Surgeons).

This study was done by the Minimally Invasive and Robotic Surgery Committee of the CBC. All members were informed about both the anonymous status of their information and their responsibility regarding the accuracy of the given information. The survey addressed demographics, years of profession and robotic training, geographical distribution, robotic training, surgical volume information, and also questions about their knowledge and opinion regarding the new robotic surgical training determination, in Brazil, according to the AMB statement published on December 17th, 2019. The latter was directed to all surgical societies that use robotic surgery, as described in Table 1.

The statistical analyses for baseline characteristics were performed by Fisher's exact test for categorical variables, and the Wilcoxon rank-sum test to examine continuous variables. Values were appropriately expressed as percentages or, as medians (interquartile ranges). For all analyses, p-value $<0.5$ was considered significant, and the STATA software version 14.0 (StataCorp, College Station, TX) was used.

\section{RESULTS}

Out of the 6.299 CBC members who received the invitation to participate in the months of March and April 2020, 294 (4.7\%) answered the query. The invitation process is described in Figure 1. The answers were split into two groups: 133 (45.3\%) answers were of members who had already received robotic console certification, and 161 (54.8\%) who did not have it. The overall distribution was also divided into the groups of surgeons who had or did not have robotic certification, and this is depicted in Table 2. Regarding the age of surgeons who answered the query, there was no difference between the two groups, as the overall median age was 46 (interquartile of $41-55$, range of $30-77$ ). However, when the time of experience as physician (years after graduation) was evaluated, the noncertified robotic group had more surgeons with at least 30 years of experience than the robotic (32.3\% versus $23.3 \%, p=0.033$ ). Although no disparities were seen regarding the major geographic country areas, surgeons with robotic certification more frequently worked in cities with at least one million inhabitants than those who were not certified (85.7 versus 63.4\%, $p<0.001$ ).

The acquaintance with the robotic recommendations and regulations were also evaluated as depicted in Table 2. Most of the surgeons (95.6\%) in both groups were aware of the FDA recommendations for the use of robotic surgery as a valid therapeutic option, as long as the surgical team receives appropriate training and certification. Concerning surgeons who were aware of both the NICE recommendation and the approval of AMB robotic statement, the robotic certified group more 
frequently reported being aware of both than those in the non-robotic group, respectively, $98.5 \%$ and $75.9 \%$ versus $88.5 \%$ and $40.4 \%, p=0.001$ and $p<0.001$.

Both groups had similar positioning for all the main topics of the statement regarding the AMB statement and the other recommendations, as demonstrated in Table 3. Nonetheless, the agreement for the mentorship responsibility during the procedures was different between groups. Non-robotic surgeons expected that the mentor should take over the co-responsibility for the procedure $(85 \%$ versus $60.9 \%, p<0.001)$ than the certified robotic surgeons. The former also expected the mentor to intervene during the procedure as much as necessary $(97.5 \%$ versus $91.7 \%, \mathrm{p}=0.033)$.

Regarding the certified robotic surgeons' group, an overview of years of experience as a physician and after robotic training is depicted in Figure 2. The median number of procedures is 20 , with a mean number of 115 procedures. Most of the surgeons (65.4\%) work in more than one area, as described in Table 4. Upper gastrointestinal (63.2\%), hernia (60.9\%), and colorectal (57.9\%) operations represented the three most common surgical procedures described by the robotic expert group. The majority of the surgeons (82.7\%) who work with robotic surgery have the opinion that the robotic platform has been a useful tool to improve their surgical skills.

Table 1. Guidelines of the Associação Médica Brasileira (AMB - Brazilian Medical Association) for certification in robotic surgery in Brazil. The minimum requirements for qualification in robotic surgery regardless the surgical specialty

1. The qualification in robotic surgery must be linked to the surgeon's specialty in the medical council.

2. The training has to be recognized by a specialty society.

3. The surgeon must have theoretical and hands on training with the components of the robotic platforms, and their operation.

4. Minimum of established hours on the simulator training platform.

5. Observation of a preceptor surgeon for a minimum number of surgeries, according to the specialty.

6. Minimum number of surgeries performed under the supervision of a preceptor surgeon.

7. The preceptor surgeon must demonstrate minimal experience in the specialty, and his certification must be certified by the AMB.

8. The use of animals is not mandatory.

9. A provisional license will be issued until the surgeon completes the requirements to receive the definitive license

10. The preceptor surgeon will be co-responsible with the training surgeon, for any damage to the patient, caused by robotic surgery.

11. The patient must be informed, in a specific document, that the training surgeon, under the supervision of the preceptor surgeon, will perform the surgery.

12. Hospital's medical director must inform the training surgeon, that the preceptor will coordinate the surgical procedure, documenting with everyone's signature.

13. The preceptor surgeon must direct the surgical actions, whenever he deems convenient, for patient safety.

14. All medical staff, including anesthetist and assistant surgeon, must be trained by the guidelines of the AMB. 
Table 2. Demographic characteristics of the 294 Brazilian surgeons who answered the query of the Colégio Brasileiro de Cirurgiões (CBC - Brazilian College of Surgeons) about the new certification process for robotic surgery in Brazil and their acknowledgement of the actual robotic recommendations.

\begin{tabular}{|c|c|c|c|c|}
\hline Characteristics & $\begin{array}{c}\text { Total } \\
\mathrm{N}=294(\%)\end{array}$ & $\begin{array}{l}\text { Robotic Group } \\
\mathrm{N}=133(45.3 \%)\end{array}$ & $\begin{array}{l}\text { Non-robotic Group } \\
\mathrm{N}=161(54.8 \%)\end{array}$ & p-value \\
\hline Age - years* & $46(41-55)$ & $46(41-54)$ & $46(40-57)$ & 0.785 \\
\hline Years after graduation & & & & 0.033 \\
\hline$\leq 5$ & $14(4.8)$ & $3(2.3)$ & $11(6.8)$ & \\
\hline$>5$ and $\leq 10$ & $21(7.1)$ & $6(4.5)$ & $15(9.3)$ & \\
\hline$>10$ and $\leq 15$ & $37(12.6)$ & $17(12.8)$ & $20(12.4)$ & \\
\hline$>15$ and $\leq 20$ & $61(20.8)$ & $34(25.6)$ & $27(16.8)$ & \\
\hline$>20$ and $\leq 25$ & $46(15.7)$ & $27(20.3)$ & $19(11.8)$ & \\
\hline$>25$ and $\leq 30$ & $32(10.9)$ & $15(11.3)$ & $17(10.6)$ & \\
\hline$>30$ & $83(28.2)$ & $31(23.3)$ & $52(32.3)$ & \\
\hline Major Brazilian Regions ${ }^{\alpha}$ & & & & 0.71 \\
\hline North & $9(3.1)$ & $1(0.8)$ & $8(5)$ & \\
\hline Northeast & $11(3.8)$ & $4(3)$ & $7(4.4)$ & \\
\hline Central-west & $24(8.2)$ & $7(5.3)$ & $17(10.6)$ & \\
\hline Southeast & $217(74)$ & $107(80.4)$ & $110(68.7)$ & \\
\hline South & $31(10.9)$ & $14(10.5)$ & $18(11.3)$ & \\
\hline Population $\times 10^{3}$ inhabitants & & & & $<0.001$ \\
\hline$\leq 200$ & $22(7.5)$ & $1(0.7)$ & $21(13)$ & \\
\hline$>200$ and $\leq 500$ & $31(10.5)$ & $9(6.8)$ & $22(13.7)$ & \\
\hline$>500$ and $\leq 1,000$ & $25(8.5)$ & $9(6.8)$ & $16(9.9)$ & \\
\hline$>1,000$ & $216(73.5)$ & $114(85.7)$ & $102(63.4)$ & \\
\hline \multicolumn{5}{|c|}{ Recognition and acquaintance with the new process of robotic surgery in Brazil } \\
\hline $\begin{array}{l}\text { NICE recommendation for robotic } \\
\text { approach }(2015)^{\beta}\end{array}$ & & & & 0.001 \\
\hline Yes & $268(93.1)$ & $130(98.5)$ & $138(88.5)$ & \\
\hline No & $20(6.9)$ & $2(1.5)$ & $18(11.5)$ & \\
\hline $\begin{array}{l}\text { FDA approval for robotic surgery } \\
\text { (2019) }\end{array}$ & & & & 0.236 \\
\hline Yes & $282(95.9)$ & $130(97.7)$ & $152(94.4)$ & \\
\hline No & $12(4.1)$ & $3(2.3)$ & $9(5.6)$ & \\
\hline AMB statement & & & & $<0.001$ \\
\hline Yes & $166(56.5)$ & $101(75.9)$ & $65(40.4)$ & \\
\hline No & $128(43.5)$ & $32(24.1)$ & $96(59.6)$ & \\
\hline
\end{tabular}

${ }^{*}$ reported as median and interquartile; ${ }^{a} n=293 ;{ }^{\beta} n=288 ;$ NICE: National Institute for Health and Care Excellence (UK); FDA: Food and Drug Administration (USA); and AMB: Associação Médica Brasileira (AMB - Brazilian Medical Association).

\section{DISCUSSION}

The use of the robotic platform has increased with many articles and societies supporting its use, worldwide. The evolution of robotic surgery has taken place in the last 35 years, with some different robotic platforms ${ }^{3}$. The first human robotic surgery was performed in 1985 using a Programmable Universal Machine for
Assembly (PUMA 200), that was used to carry out a neurosurgical biopsy'. The system was preoperatively programmed based on fixed anatomy landmarks, and this explains why it could not be applied to general surgery 3 . In this regard, the need for fixed landmarks limited the application for abdominal and thoracic surgery, since in both anatomic areas, the pneumoperitoneum leads to organ mobilization and deformation which was an 
important drawback. Although the first human robotassisted cholecystectomy was performed in Belgium using an Intuitive prototype called "Mona", the FDA approved the da Vinci® platform as robot-assisted surgery for general surgery, after at least 300 surgeries, on July 17th, 2000. In 2001, the first robot-assisted telesurgery was carried out by a surgeon on the console in New York and the patient in Strasbourg, France, using the prototype ZEUS (Computer Motion, California) 4 . In 2003, both Computer Motion and Intuitive merged their business, and the da Vinci® platform was launched while the Zeus was discontinued.

Table 3. Proportion of agreement with the recommendations of the Associação Médica Brasileira (AMB - Brazilian Medical Association) statement (2019) of robotic surgical certification in Brazil.

\begin{tabular}{|c|c|c|c|c|}
\hline Query & $\begin{array}{c}\text { Total } \\
\mathrm{N}=294(\%)\end{array}$ & $\begin{array}{l}\text { Robotic Group } \\
\mathrm{N}=133(45.3 \%)\end{array}$ & $\begin{array}{l}\text { Non-robotic Group } \\
\mathrm{N}=161(54.8 \%)\end{array}$ & p-value \\
\hline $\begin{array}{l}\text { Training and certification to } \\
\text { robotic platform by* }\end{array}$ & & & & 0.302 \\
\hline Industry (actual) & $5(2.5)$ & $4(4.7)$ & $1(0.9)$ & \\
\hline Medical entities & $193(94.6)$ & $80(93)$ & $113(95.8)$ & \\
\hline Medical entities + industry & $5(2.5)$ & $2(2.3)$ & $3(2.5)$ & \\
\hline Without opinion & $1(0.5)$ & 0 & $1(0.9)$ & \\
\hline $\begin{array}{l}\text { Acquaintance with the CBC \& } \\
\text { other medical societies }\end{array}$ & & & & 0.217 \\
\hline Yes & $268(91.2)$ & $118(88.7)$ & $150(93.2)$ & \\
\hline No & $26(8.8)$ & $15(11.3)$ & $11(6.8)$ & \\
\hline $\begin{array}{l}\text { Need of the specialist registration } \\
\text { into the Regional Medical Council }\end{array}$ & & & & 1 \\
\hline Yes & $278(94.6)$ & $126(94.7)$ & $152(94.4)$ & \\
\hline No & $16(5.4)$ & $7(5.3)$ & $9(5.6)$ & \\
\hline Need of provisory habilitation ${ }^{\alpha}$ & & & & 0.893 \\
\hline Yes & $219(74.7)$ & $100(75.2)$ & $119(74.4)$ & \\
\hline No & $74(25.3)$ & $33(24.8)$ & $41(25.6)$ & \\
\hline $\begin{array}{l}\text { Preceptor as co-responsible of the } \\
\text { surgical procedure }\end{array}$ & & & & $<0.001$ \\
\hline Yes & $217(74.1)$ & $81(60.9)$ & $136(85)$ & \\
\hline No & $76(25.9)$ & $52(39.1)$ & $24(15)$ & \\
\hline $\begin{array}{l}\text { Preceptor on duty of intervention } \\
\text { during the surgical procedure }^{a}\end{array}$ & & & & 0.033 \\
\hline Yes & $278(94.9)$ & $122(91.7)$ & $156(97.5)$ & \\
\hline No & $15(5.1)$ & $11(8.3)$ & $4(2.5)$ & \\
\hline $\begin{array}{l}\text { Need of training of the surgical } \\
\text { team }\end{array}$ & & & & 0.624 \\
\hline Yes & $250(85.3)$ & $112(84.2)$ & $138(86.3)$ & \\
\hline No & $43(14.7)$ & $21(15.8)$ & $22(13.7)$ & \\
\hline
\end{tabular}

${ }^{*} n=204 ;{ }^{a} n=293$, Colégio Brasileiro de Cirurgiões (CBC - Brazilian College of Surgeons). 


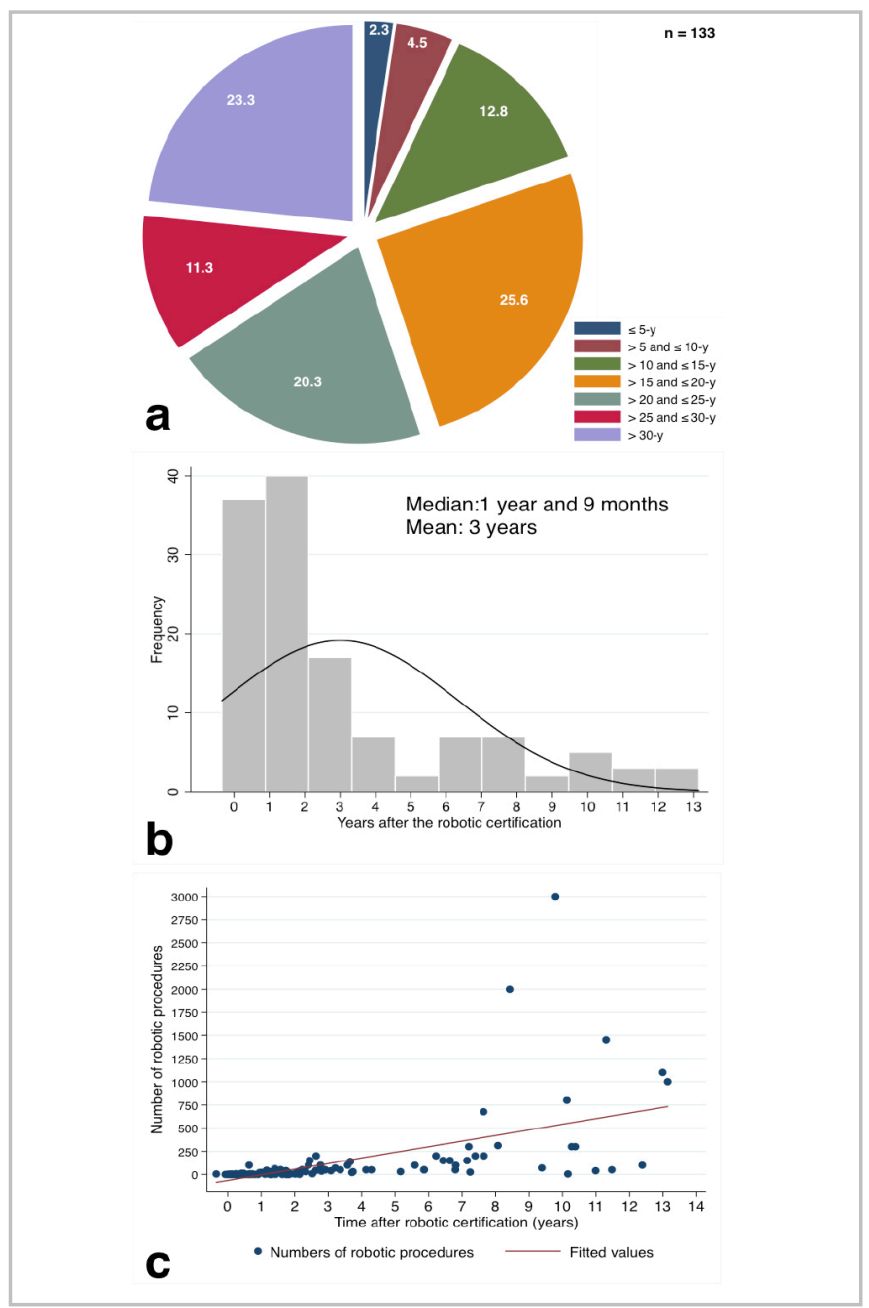

Figure 2. Surgical experience among the 133 surgeons who have robotic certification. 2a: distribution of surgeons according to the time after medical graduation; $2 b$ : distribution of surgeons according to the time after robotic certification; and 2c: scatterplot of the total number of procedures by each surgeon according to the time after robotic certification.
Table 4. Distribution of robotic group (133 surgeons) according to the acting areas of surgery and impression about robotic surgery.

\begin{tabular}{lc}
\hline \multicolumn{1}{c}{ Number of acting area by surgeon (\%) } \\
\hline 1 & $46(34.6)$ \\
2 & $10(7.5)$ \\
3 & $16(12)$ \\
4 & $26(19.6)$ \\
5 & $28(27.1)$ \\
6 & $7(5.3)$
\end{tabular}

Number of surgeons by each acting area (\%)

Upper Gastrointestinal (Esophagus

and Stomach)

$84(63.2)$

Hernia

Colorectal

Cholecystectomy

Hepato-Pancreato-Biliary (Liver, Bile Ducts and Pancreas)

Gynecology

Urology

Thoracic

Head and Neck

$3(2.3)$

Personal impression about the robotic approach in their surgical practice

\begin{tabular}{lc}
\hline No differences in practice & $13(9.8)$ \\
More difficult than laparoscopy & $10(7.5)$ \\
Overall improvement & $110(82.7)$ \\
\hline
\end{tabular}

The main putative advantage of the robotic system is the tridimensional view since two cameras are used to provide a more precise surgical field view when compared to the dimensional laparoscopic view, both using the magnification; the stability of the image is an important aspect since the camera is also operated by the surgeon and its motion can be static as much as the surgeon wants it. The robotic platform increases both the ergonomics and coordination of the surgical team; and perhaps the most valuable contribution of the system is the Endo Wrist technology that preserves the movements of the human hand-pincers, with more degrees of freedom than laparoscopy. On the other hand, the limitations of the tactile sensation in robotic surgery are more important than with the laparoscopic approach, which is also limited. The development of new eye-haptic skill for the robotic approach is a common skill usually assimilated in the learning curve ${ }^{5}$.

Another limiting issue of robotic acceptance and diffusion is the higher costs compared to laparoscopy. Although the costs to pay for the initial investments regarding acquisition and maintenance of the robotic platforms, their diffusion in both Eastern and Western countries has increased. There are currently 5.669 da Vinci® platforms in the world, and 74 in Brazil, on March 31, 20206. In Brazil, there are about 1,500 certified surgeons to perform robotic surgery, and near $10 \%$ answered this web-national survey. 
Our survey arose from the need to assess the knowledge concerning the new BMA statement among the surgeons. This statement declares common points that must be adopted by all the medical societies that use the robotic platform as a modality of treatment. The overall distribution of the surgeons indicated that most of them live in bigger cities, with more than one million inhabitants, from the Southeast of Brazil, and with at least 10 years of medical practice. Moreover, most of them stated they were aware of the approval of the robotic platform by FDA and the NICE. The majority of the surgeons also agreed with the importance of the training and certification provided by medical entities, regardless $\mathrm{CBC}$ or not. The surgeons stated there is a need to at the medical council on subject specialty, agree with the need for a provisory license, the need of training of the whole surgical team, not only for the main surgeon, and the role of the preceptor as co-responsible for surgical procedure and on duty for intervention as much as necessary.

However, expecting a putative biased view between surgeons who performed or not robotic surgery, both groups were compared on the survey. The main differences are that the robotic group has fewer surgeons with more than 30 years practice; more surgeons working in bigger cities; more surgeons demonstrated awareness of the NICE recommendations and knowledge about the AMB statement. Although the majority of both groups agreed about the preceptor as co-responsible and on duty for intervention as much as needed, the agreement proportion for them was higher and the non-robotic group. These answers suggest that the referee physician of the patient is concern about the involvement of the preceptor in the surgical outcome, as well as they, are also a concern to receive the appropriate aid during the intervention as much as necessary. Although the proctoring assumes a role in the development of new surgical skills, it is not simply characterized as training since all physicians involved in the procedure have coresponsibility with the health of the patient, regardless of their role as a surgeon, assistant, preceptor or anesthesiologist.

Regarding specifically the robotic group, they represented approximately $9 \%$ of the surgeons certified for robotic surgery in Brazil, being $80.4 \%$ in the Southeast, and $85.4 \%$ working in cities with at least one million inhabitants, that it is also close to the overall distributions of the 74 robotic platforms in Brazil with $71 \%$ in the Southeast; $13 \%$ in the combined North/ Northeast; $8 \%$ in the Central-West; and 8\% in the South of Brazil ${ }^{6}$. Concerning a surrogate for surgical experience, years after medical graduation and years after robotic certification were measured, most of them were between 10 to 20 years after graduation and they represented, mostly, surgeons with approximately 21 months with experience in robotic surgery. Only one-third of them work exclusively in one sub-area of general surgery and specialties. It corroborates with both the scope of the $\mathrm{CBC}$ and the overall general surgery practice in Brazil, in which the surgeons usually work in more than one of the subarea listed in this survey. The majority of the robotic surgeons, as demonstrated in Figure 2, still have little experience (median of 20 procedures) that it opposes for few surgeons with higher volume, given rise to a skewed distribution for a mean number of procedures (115 procedures). Regarding the personal impression of the robotic platform in their surgical practice, $80 \%$ of the surgeons noticed an overall improvement of their technical skills with its use.

The limitations of this study are those related to cross-sectional studies, thus, causal relationships were not possible. Neither surgical indications nor surgical outcomes were the scope of this survey since the objective was the approach to the new regulation process for robotic surgery in Brazil and not the results from robotic surgery itself. Although a previous study suggests the responders of web-survey have more interest if they expertise and clinical practice in the subject area, the majority of the surgeons who answered this national web-survey did not have robotic certification? ${ }^{7}$. Contrary, although both groups have a different profile, many surgeons who have not performed robotic surgery have interest and concern about this topic. Perhaps the most important limitation of our study was low number of answers, representing $4.7 \%$ of CBC members. However, looking at the robotic group, they represent almost $9 \%$ of robotic surgeons certified in Brazil. Both numbers of total and robotic groups were beneath our initial expectations, and its fact claims for more participation of $C B C$ members in collaborations from $\mathrm{CBC}$ rather than this small subgroup. By contrast, even this small number was large enough to 
detect significant differences between groups and also to show that the transition for the new robotic certification process in Brazil should have support for both certified and not-yet certified surgeons in Brazil.

While some differences were detected, mainly for the profile of each group, the similarities especially for both acknowledgment and acceptance for the new regulation is crucial and favorable to the transition of the new certification process in Brazil. They are congruent with the interest of both $A M B$ and $C B C$ members. This survey and its overall agreement to the AMB statement seem to be a promising pathway to increase the participation of the medical entities into the robotic certification process in Brazil.

\section{R E S U M O}

Objetivo: avaliar o perfil do cirurgião robótico brasileiro e seu reconhecimento sobre o novo processo de certificação para cirurgia robótica que consta na declaração da Associação Médica Brasileira (AMB). De acordo com a declaração da AMB, as sociedades médicas e os preceptores devem alcançar papéis de liderança no treinamento e certificação de cirurgiões, atuando em parceria com a indústria. Métodos: uma pesquisa nacional pela Internet foi promovida pelo Colégio Brasileiro de Cirurgiões com seus membros. Resultados: entre as 294 respostas, os cirurgiões foram divididas em dois grupos: 133 (45,3\%) que possuíam certificação de console robótico e 161 (54,8\%) que não possuíam. A média geral de idade foi de 46 anos, mas o grupo não robótico teve mais cirurgiões com pelo menos 30 anos de experiência (32,3\% versus $23,3 \%, p=0,033$ ). Cirurgiões com certificação robótica trabalhavam mais frequentemente em cidades mais populosas, com pelo menos um milhão de habitantes $(85,7$ versus 63,4\%, $p<0,001)$. A maioria dos cirurgiões de ambos os grupos tem posicionamento semelhante para todos os pontos principais da declaração. No entanto, as proporções de concordância para a responsabilidade do preceptor durante os procedimentos foram maiores entre os cirurgiões não robóticos que esperavam que o preceptor assumisse corresponsabilidade pelo procedimento (85\% versus $60,9 \%, p<0,001)$, e que intervenha, tanto quanto necessário $(97,5 \%$ versus $91,7 \%, p=0,033)$. Conclusão: a aceitação por parte da maioria dos profissionais em relação à declaraçãoda $A M B$ parece ser caminho promissor para aumentar a participação das entidades médicas na certificação robótica no Brasil.

Palavras chave: Certificação. Procedimentos Cirúrgicos Minimamente Invasivos. Robótica. Treinamento por Simulação.

\section{REFERENCES}

1. Kwoh YS, Hou J, Jonckheere EA, Hayati S. A robot with improved absolute positioning accuracy for CT guided stereotactic brain surgery. IEEE Trans Biomed Eng. 1988;35(2):153-60.

2. Associação Médica Brasileira. Normas para Habilitação em Cirurgia Robótica. 2019.

3. Leal Ghezzi T, Campos Corleta O. 30 Years of Robotic Surgery. World J Surg. 2016;40(10):25507.

4. Marescaux J, Leroy J, Gagner M, Rubino F, Mutter D, Vix M, et al. Transatlantic robot-assisted telesurgery.
Nature. 2001;413(6854):379-80.

5. Seminara L, Gastaldo P, Watt SJ, Valyear KF, Zuher F, Mastrogiovanni F. Active Haptic Perception in Robots: A Review. Front Neurorobot. 2019;13:53.

6. Surgical Intuitive [Internet]. Investor Overview. 2020. Available from: http://isrg.gcs-web.com

7. Paiva CE, Araujo RL, Paiva BS, de Pádua Souza C, Cárcano FM, Costa MM, Associação Médica Brasileira. What are the personal and professional characteristics that distinguish the researchers who publish in high- and low-impact journals? A multinational web-based survey. Ecancermedicalscience. 2017;11:718.
Received in: 08/07/2020

Accepted for publication: 27/08/2020

Conflict of interest: no.

Funding source: none.

\section{Mailing address:}

Raphael L. C. Araujo

E-mail: raphael.araujo@unifesp.br

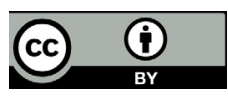

